\title{
ФОРМУВАННЯ УСНОГО УКРАЇНСЬКОГО МОВЛЕННЯ РОСІЙСЬКОМОВНИХ ПЕРШОКЛАСНИКІВ: МЕТОДИЧНІ АСПЕКТИ
}

\author{
ТЕТЯНА ЛОЗАН \\ Рибницька філія Придністровського державного \\ університету імені Тараса Шевченка, \\ українська середня загальноосвітня школа № 1, Рибниця - Придністров’я \\ WYBRANE ASPEKTY METODYKI KSZTAŁTOWANIA UKRAIŃSKIEJ \\ MOWY USTNEJ ROSYJSKOJĘZYCZNYCH UCZNIÓW KLAS PIERWSZYCH
}

\author{
TETIANA LOZAN \\ Rybnicka filia Naddniestrzańskiego Państwowego \\ Uniwersytetu imienia Tarasa Szewczenki, \\ Ukraińska ogólnokształcąca szkoła średnia nr 1, Rybnica - Naddniestrze
}

STRESZCZENIE. W artykule przeanalizowane zostały wybrane aspekty metodyki kształtowania ukraińskiej mowy ustnej rosyjskojęzycznych uczniów klas pierwszych, w szczególności formowanie umiejętności częściowo- i ogólnojęzykowych oraz komunikatywnych. Podjęta została próba określenia głównych rodzajów i kierunków pracy w zakresie rozwoju mowy ustnej.

\section{ORAL UKRAINIAN SPEECH FORMATION OF THE RUSSIAN SPEAKING FIRST-FORM PUPILS: METHODOLOGICAL ASPECTS}

\author{
TETIANA LOZAN \\ Rybnitsa Branch of Pridnestrovian Taras Shevchenko State University \\ Ukrainian Comprehensive School \# 1, Rybnitsa — Pridnestrovie
}

ABSTRACT. The article deals with the analysis of some aspects of the methodology of forming the Ukrainian spoken language of the Russian speaking first-form pupils, in particular the formation of the partly and general speech and communicative skills. The attempt has been made to define basic kinds and directions in work that aims at developing of oral speech.

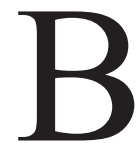

ідродження національної школи і реформування освіти в Придністров ї $\epsilon$ вимогою часу. Цей процес зумовлений змінами в суспільно-політичному житті і засвідчений „Законом про мови”, концепцією викладання офіційних мов і літератур. Із зміною соціально-політичних функцій української мови, наданням їй статусу офіційної на конституційному рівні спостерігаємо переорієнтацію мети навчання мови в освітніх закладах Придністров’я.

Оскільки Придністров'я $є$ багатомовним, і до українських шкіл приходять російськомовні діти, то пошуки шляхів ефективного розвитку українського мовлення російськомовних першокласників є однією 3 важливих проблем.

1 Закон ,Про мови в Придністровській Молдавській Республіиі”, Тирасполь 1993. 
Першочерговість завдань з розвитку мовлення визначається необхідністю оволодіння українською мовою, умінням спілкуватися нею, оскільки вона $€$ мовою, якою викладають усі предмети.

Метою цієї статті є спроба визначити основні види та напрямки роботи 3 формування усного українського мовлення російськомовних першокласників в умовах Придністров'я.

Вихідними положеннями методики формування й розвитку усного українського мовлення стали психологічні та психолінгвістичні дослідження Л. Виготського, І. Зимньої, О. М. Леонтьєва, О. О. Леонтьєва та ін., що стосуються мовленнєвої діяльності; дані психолінгвістики та лінгводидактики про сутність мовленнєвих умінь та послідовність їх формування (В. Артемов, М. Баранов, Б. Біляєв, Т. Ладиженська, М. Львов, С. Рубінштейн та ін.); дані досліджень, що стосуються методики навчання близькоспоріднених мов (О. Біляєв, Г. Коваль, Н. Пашківська, А. Супрун, О. Хорошковська та ін.).

За державними стандартами загальної освіти Придністров'я вимоги рівня загальноосвітньої підготовки учнів початкової школи з української мови визначають принципи розвитку чотирьох традиційних видів мовленнєвої діяльності: слухання - розуміння, говоріння, читання і письмо ${ }^{2}$. Розглянемо два види мовленнєвої діяльності: слухання - розуміння й говоріння.

Важливість та необхідність цих видів мовленнєвої діяльності в процесі навчання грамоти обгрунтував В. Горецький: „Слухання і говоріння становить фундамент, першооснову формування писемних форм мовлення. Увага до вдосконалення й розвитку усних видів мовлення повинна бути не менш важливою, ніж до вироблення писемних видів. Завдання розвивати й вдосконалювати в кожного учня вміння уважно слухати й говорити ясно й усвідомлено це справа не менш значна, ніж проблема навчання елементарному читанню й письму"з.

В умовах навчання російськомовних першокласників очевидною є необхідність формувати такі уміння українського мовлення: аудіативні, орфоепічні й граматичні, необхідно також збагачувати словниковий запас, розвивати уміння діалогічного й монологічного мовлення, що створить базу для навчання читання й письма.

Під час формування умінь усного українського мовлення необхідно враховувати лінгводидактичні принципи навчання української мови російськомовних учнів: принципи випереджувального формування усного мовлення щодо писемного, мотивації навчального процесу, комунікативної спрямованості навчання, комплексного підходу до формування мовленнєвих умінь, забезпечення мовленнєвого середовища, міжпредметних зв'язків.

Ефективність формування усного мовлення залежить від доцільного використання методів навчання. Серед пізнавальних методів рекомендуємо застосовувати пояснювально-ілюстративний метод, а серед тренувальних — імітаційний, репродуктивний, оперативний, комунікативний методи.

На основі зазначених принципів, методів і прийомів та системи вправ авторка цієї статті розробила лінгводидактичну модель розвитку українського мовлення учнів перших класів, що охоплює три етапи: підготовчий, формувальний, продуктивно-творчий.

${ }^{2}$ Т. А. Лозан, Збірник нормативного і програмного супроводу з навчального предмета „, Украйнська мова. Читання. Початкові класи”, Тирасполь 2009, с. 27.

${ }^{3}$ В. Г. Г о р е ц к и й, О возможных вариантах обучения детей грамоте, [в:] „Начальная школа", 2000, № 7, с. 35-46. 
Виходячи з того, що для російськомовних українців Придністров’я вивчення української мови в школі з українською мовою навчання $є$ не лише предметом, а й засобом навчання, оскільки сприяє розумінню й засвоєнню інших навчальних предметів, доцільно було б продовжити (хоча 6 до 6 тижнів) та наповнити новим змістом підготовчий (добукварний) період навчання грамоти, зокрема приділити більше уваги цілеспрямованому свідомому (на основі знань) формуванню частковомовленнєвих і загальномовленнєвих умінь українського мовлення.

На сьогодні в Придністров’ї відсутні підручники для шкіл з українською мовою викладання, тому в навчальному процесі рекомендовано використовувати підручники України. Аналіз змісту підручників „Українська мова"4 та „Буквар” дає змогу використовувати матеріал цих підручників, проте засвідчує, що для українських шкіл Придністров'я, де навчаються російськомовні першокласники, їх недостатньо. У зв'язку з цим було розроблено дидактичний матеріал з розвитку мовлення: доповнено й розширено мовленнєву тематику та дібрано матеріал для розвитку вмінь аудіювання, формування частковомовленнєвих та мовленнєвих умінь.

Роботу над формуванням українського мовлення необхідно проводити комплексно. Насамперед на кожному уроці вчитель повинен передбачати роботу з удосконалення аудіативних умінь, а також формування орфоепічних і граматичних умінь, збагачення словникового запасу, розвиток мовленнєвих та комунікативних умінь.

Починаючи 3 підготовчого періоду, відбір вправ слід здійснювати відповідно до мети та завдань кожного етапу навчання, керуючись принципом комплексного підходу до процесу засвоєння знань і формування мовленнєвих умінь. Значну увагу необхідно приділяти заучуванню напам'ять скоромовок, загадок, невеликих віршів, що сприяє формуванню частковомовленнєвих умінь. Наприклад, опрацювання теми „Овочі. Фрукти” можна здійснити в такий спосіб. Слухання української народної пісні „Ходить гарбуз по городу” сприятиме розвитку аудіативних умінь: 1) учні, слухаючи пісню, визначають слова назви овочів (сплескуючи в долоні), 2) обирають правильну відповідь на тестові запитання за змістом сприйнятого на слух. Матеріал підручника „Українська мова"6 - предметні малюнки, дають можливість повправляти дітей у твердій вимові приголосних перед [и], чіткій вимові голосних [о] та [а] (цибуля, посадили, виросли; картопля, помідор, гарбуз, багато). Додатково добираємо спеціальні орфоепічні вправи (чистомовки), що сприяли б закріпленню норм вимови. Робота над лексикою передбачає збагачення словникового запасу такими словами, як: морква, цииуля, картопля, огірок, кавун, гарбуз, квасоля, полуниці; семантизацію слів (за допомогою загадок та відповідних їм предметних малюнків); уточнення значення слів (кавун - арбуз (рос.), гарбуз - тыква (рос.); тренінг для їх вимовляння. Опрацювання цієї теми сприяє формуванню відповідних граматичних форм: а) узгодження іменників з прикметниками та числівниками (три огіркu, n'ять циибулин); б) вживання слів — назв предметів у формі місцевого відмінка $з$ прийменниками в, на (в ящику, на городi); в) питальні слова: щзо?, хто?; та відповідь на запитання вчителя за змістом сюжетних малюнків (Хто (щз) робить?) з метою вживання лексем, що повинні бути засвоєни-

\footnotetext{
${ }^{4}$ О. Н. Хорошковська, Г. І. Охота, Украӥнська мова (підручник) 1 клас, Кийв 2007.

${ }^{5}$ М. С. Вашуленко, М. Ф. Скрипченко, Буквар (підручник), Київ 2005.

${ }^{6}$ О. Н. Хорошковська, Г. І. Охота, Зазнач. джерело, с. 22-23.
} 
ми. Автоматизація зазначених частковомовленнєвих навичок може відбуватися в процесі побудови діалогу „Овочі і фрукти” та складанні опису овочів і фруктів за зразком.

Відомо, що усне мовлення характеризується низкою засобів виразності: інтонація, темп мовлення, сила та тембр голосу. Саме тому в процесі розвитку мовлення значну увагу необхідно приділяти формуванню вмінь володіти інтонаційними можливостями голосу (інтонацією, силою голосу, темпом мовлення) і використовувати їх у процесі спілкування залежно від комунікативної ситуації. Засоби виразності мовлення доцільно відпрацьовувати у процесі промовляння скоромовок. Доцільними в цьому напрямі $є$ такі види роботи, як спостереження за інтонацією (під час слухання художніх творів), аналіз мовленнєвих зразків 3 огляду на засоби виразності; вибір відповідної інтонації реплік (героїв оповідань, казок, дійових осіб рольових ігор) на основі індивідуальних характеристик мовців та мети їх висловлювань. Особливу увагу під час інсценування казок слід звертати на виразність промовляння реплік героїв. Учні можуть вправлятися в передаванні голосом різноманітних інтонаційних відтінків: радості, суму, здивування.

Відтворення діалогів можна здійснювати шляхом інсценування казок із відтворенням завчених реплік героїв, оскільки в учнів уміння українського мовлення сформовані ще недостатньо. Першокласники відтворюватимуть репліки героїв казок Ріпка, Телесик, Горщик каші, Лисиия $і$ вовк, Рукавичка, Котик $i$ півник та ін. і вчитимуться промовляти їх із потрібною інтонацією під час розігрування, використовуючи малюнки з підручника ${ }^{7}$. Така робота $є$ корисною, оскільки в діалогах функціонує багато звертань: „Ходи, бабусю (доню, Хвіночко, Варварочко, Сірочко)” (казка Ріпка); „Поїдь, діду”, „, Зробіть мені, тату”, „Телесику”, „Ближче, човнику”, „Ковалю” та ін. (казка Телесик); „Добрий день, дівчинко”, „Бабусю”, „Горщику” (казка Горщиик каші); „Півнику-братику”, „Мій котику, мій братику!” (казка Котик і Півник). Відтворення реплік у ході інсценізації казок дає змогу сформувати й розвинути чуття української мови в російськомовних учнів, зокрема сформувати вміння звертатися, використовуючи кличний відмінок.

Для слухання на підготовчому етапі рекомендуємо використовувати короткі народні казки, вірші, оповідання. Спочатку необхідно пояснити незнайомі дітям слова, ілюструючи їх малюнками чи предметами. На початковому етапі вчителю краще розповідати, а не читати казки та вірші. А згодом можна перевірити розуміння змісту тексту. Наприклад, вибрати малюнок, що відповідає змісту прослуханого (пропонується 2-3 малюнки, близькі за змістом, один з яких повністю відповідає тексту); перелічити дійових осіб, які зустрічаються в тексті; із прочитаних тверджень вибрати правильні, показавши картку із знаком „,"”.

Вправами на уміння будувати найпростіші висловлювання на цьому етапі можуть бути такі: складання речень за заданою графічною схемою; формулювання відповіді на запитання вчителя (найпоширенішою структурною схемою діалогу є сполучення двох реплік: запитання і відповіді); відтворення (за ролями) діалогів із прослуханих казок, розповідей за аналогією про себе, свій дім, клас, школу; переказування невеликого прослуханого тексту з опорою на подані словосполучення, запитання.

Навчання побудові власних висловлювань слід розпочинати із складання розповіді за зразком учителя. Ефективним уважаємо використання прийо-

\footnotetext{
${ }^{7}$ О. Н. Хорошковська, Г. І. Охота, Зазнач. джерело, Київ 2007.
} 
му розповіді за аналогією. Навчаючи, наприклад, дітей розповідати про родину, вчитель спочатку сам розповідає про себе і свою родину, демонструючи зразок такої розповіді. У такий спосіб одночасно закріплюємо орфоепічні вміння, удосконалюємо граматичні вміння й активізуємо пасивний словниковий запас школярів.

Оскільки процес формування українського мовлення в російськомовних першокласників відбувається в процесі активізації сформованих умінь шляхом участі в найпростіших мовленнєвих ситуаціях, то застосування комунікативного методу має місце вже в добукварний (підготовчий) період. У процесі вивчення теми „Одяг $i$ взуття” для закріплення етикетної лексики (слів увічливого вітання, прохання, подяки, прощання) можна створити таку мовленнєву ситуацію: діти отримують „лист” від тата Карло з казки Золотий ключик або пригоди Буратіно, в якому він звертається до школярів із проханням надіслати Буратіно одяг і взуття, адже він ,щойно народився”. Для цього потрібно з серії предметних малюнків дібрати для Буратіно взуття та одяг. На кожній парті в одного $з$ учнів лежить лише конверт, в іншого - тільки малюнки. Кожен із дітей, у яких немає конверту чи малюнків, має ввічливо попросити їх, звернувшись до вчителя. Потім кожен учень розповідає, що він надсилає Буратіно. Створення цієї ситуації має на меті введення в активний словник учнів слів увічливості, назв одягу та взуття, засвоєних на минулому уроці; активізацію українських форм звертання до вчителя; формування комунікативної поведінки в ситуаціях, де потрібно попросити або подякувати.

Під час таких ігрових мовленнєвих ситуацій у молодших школярів активізується запам'ятовування мовленнєвих штампів, що виражають різноманітні смислові та емоційно-експресивні явища, наприклад, вітання: здрастуй, привіт, доброго ранку, доброго дня, доброго вечора; прохання: будь ласка, прошу, будьте ласкаві; прощання: до побачення, бувайте здорові, прощзавайте, на все добре, добраніч, щзасливо, до зустрічі; впевненість у чомусь: обов'язково, звичайно; відповідь на вдячність: будь ласка, нема за щзо тощо.

Ураховуючи важливу особливість дитячої психології, що полягає в природній потребі дітей гратися, слід активно використовувати ігрові прийоми. Гра, зокрема сюжетно-рольова, - один із оптимальних, природних способів організації мовленнєвого спілкування дітей. Дидактична гра $є$ органічною частиною уроку: у формі ігор або ігрових ситуацій подаємо звичайні вправи, замасковані в цікаву форму, тим самим попереджаємо психічні перевантаження дітей від одноманітного тренування.

Отже, домінуюча роль на підготовчому етапі відведена передмовленнєвим та умовно-мовленнєвим вправам, пояснювально-ілюстративному, імітаційному та репродуктивному методам.

Якщо впродовж добукварного (підготовчого) періоду основну увагу приділяємо формуванню частковомовленнєвих і мовленнєвих умінь (репродуктивне мовлення), то протягом букварного (формувального) та післябукварного (продуктивно-творчого) — комунікативних (продуктивне мовлення), що формуватимуться на уроках, і відбуватимуться в ситуаціях спілкування, природних або штучно змодельованих.

На другому (формуючому) етапі ставимо мету вдосконалити частковомовленнєві та загальномовленнєві вміння, сформовані на підготовчому етапі, та сформувати комунікативні вміння. Для досягнення поставленої мети слід активно використовувати умовно-мовленнєві вправи, що сприяють удоско- 
наленню й автоматизації частковомовленнєвих умінь та навичок. Особливу роль на цьому етапі відведено репродуктивному та комунікативному методам. У цей період учні в основному повинні вправлятися в аудіюванні невеликих текстів, що належать до художнього й розмовного стилів (казка, розповідь, вірш); у процесі вивчення букв слід використовувати орфоепічні вправи і завдання навчального, розвивального, проблемного, тренувального та ігрового характеру. Орфоепічні вправи рекомендуємо реалізовувати через використання артикуляційних (вправи на рухи й положення органів артикуляційного апарату), слухових (вправи на розвиток фонематичного сприймання, розвиток здатності сприймати на слух звуки мовлення, диференціювати їх у словах як змісторозрізнювальні одиниці).

Основну увагу в процесі проведення словникової роботи на формуючому етапі приділяємо уточненню значення слів та активізації слів у мовленні. Уточнення значення слів повинно відбуватися на основі протиставлення антонімів і зіставлення слів, близьких за значенням (верхній - нижній, довгий - короткий, внизу - вгорі, більше - менше, близько - далеко; сміливий безстрашний), на засвоєнні відтінків значень слів (котики, лисички).

У роботі над уточненням і розширенням словника рекомендуємо застосовувати такі вправи: виконання завдань на добір або вилучення слів 3 певним значенням (дібрати слова - назви ознак, дій до назв предметів на малюнках і навпаки); введення поданих слів у речення чи тексти (складання речень за опорними словами тощо). Роботу з активізації словника скеровуємо на використання нових слів, висловів у власному мовленні дітей. Вправи підбираємо так, щоб в активному словнику дітей були назви дій, станів, ознак (колір, форма, величина, смак), властивостей і якостей; слова, що виражають видові (назви окремих предметів), родові (фрукти, посуд, іграшки, транспорт та ін.) і абстрактні узагальнені поняття (добро, зло, краса та ін.).

Формуючи граматичні уміння, доцільно використовувати різні види конструктивних вправ (з поданих слів утворити словосполучення, речення). Обов'язковими мають бути завдання до низки слів, запропонованих на сторінках Букваря, а також підібрані матеріали для вивчення певного звука чи літери.

Роботу з розвитку мовлення слід проводити комплексно, наприклад на уроці за темою „Звуки [ л ], [ л'], позначення їх буквами Лл” можна запланувати такі завдання, як: формування умінь слухати - розуміти українську мову (після слухання оповідання В. Сухомлинського Biдлітають журавлі учні відповідатимуть на тестові запитання); удосконалювати вимову твердих приголосних перед [и]: хлопчик, дівчинка, малина, лимон, ловили, лисичка, пензлик, ялинка, кораблик, вони, голубий, зелений; чітка вимова звука [о] в ненаголошеній позиції: молоко, ловили; удосконалення використання граматичних форм: закінчень іменників I і II відмін у місцевому відмінку однини: $y$ лісі, на стіні, на малюнку, на парті, на стільиі), дієслів теперішнього часу в 3-й особі однини: сидить, стоїь, думає, дивиться, малює, фарбує. У процесі бесіди за змістом малюнка ${ }^{8}$ та складання опису лисички відбувається автоматизація зазначених частковомовленнєвих умінь. На даному етапі рекомендуємо розпочинати системне навчання діалогу, що має таку послідовність: уміння вступати в діалог, навчання спілкування в межах елементів діалогу; завдання на репродуктивне й продуктивне діалогічне мовлення. Інсценізуючи казки, діти вже не тільки відтворюватимуть репліки героїв казок 3 відповідною інтонацією, а й будуть

\footnotetext{
${ }^{8}$ М. С. Вашуленко, М. Ф. Скрипченко, Зазнач. джерело, с. 38-39.
} 
імпровізувати, передаючи основний зміст реплік героїв своїми словами. 3 розвитку діалогічного мовлення виділяємо вміння створювати й розігрувати діалог відповідно до запропонованої вчителем ситуації та мети спілкування (мовленнєвого завдання). Найбільш дієвим напрямком формування діалогічного мовлення $\epsilon$ складання діалогу шляхом створення мовленнєвих ситуацій (природних і штучних). У природних мовленнєвих ситуаціях існують природні стимули мовлення, що визначають мету спілкування, наприклад, хтось із учнів класу переміг у конкурсі чи в когось день народження, однокласники хочуть (мотив) привітати свого товариша 3 перемогою чи днем народження. Природні мовленнєві ситуації репрезентують позитив, оскільки, беручи участь у таких ситуаціях, учні не помічають, що навчаються, вітаючи переможця, іменинника, діти активізують відповідну лексику, навчаються планувати побажання залежно від конкретного співрозмовника, а звертаючись за столом до сусіда з проханням подати щось, навчаються ввічливо звертатися, вживати відповідну лексику і т. ін.

Малюнки та словесні описи — найчастіше вживані засоби ситуативної наочності. Опис ситуації має переваги над ситуативними малюнками. За допомогою словесного опису можна повідомити такі обставини ситуації, які не можна зобразити. Кожен із цих засобів можна використовувати окремо, але ефективніше їх поєднувати, тобто показувати ситуативні малюнки і доповнювати цей процес словесним описом ситуації.

Розвитку комунікативно-мовленнєвих умінь сприяють сюжетно-рольові ігри. Учителі при цьому здійснюють керівництво ігровою діяльністю: організовують початок гри, спонукають до участі дітей; спостерігають за грою, проектують розвиток гри, використовуючи непрямі методи керівництва (проблемні ігрові ситуації, питання, поради, нагадування та ін.); інколи включаються в гру на головних або другорядних ролях, навчають грі (показ, пояснення); обговорюють і оцінюють їі. Пропозицію пограти у „,Крамнищюю ”, ,Школу”, ,, Сім 'ю”, „,Лікарню”, ,Транспорт”, „День народження” учні завжди приймають охоче.

На формуючому етапі слід удосконалювати уміння монологічного мовлення: переказування тексту, побудова власних висловлювань за аналогією, складання розповіді за поданим початком, малюнком. Для переказування тексту, сприйнятого на слух, доцільно створювати мовленнєві ситуації, що орієнтували б мовлення учнів на певного слухача або групу слухачів, тобто мали комунікативне спрямування, наприклад, можна запропонувати одним учням зіграти роль старшого братика чи сестрички і розповісти меншому казочку перед сном. „Старші” переказують прослухану казку своїм сусідам — „меншим”.

Іншими прикладами переказування із створенням мовленнєвої ситуації можуть бути такі: після слухання казки Колобок пропонуємо учням уявити себе Колобком і розповісти сусідові, з ким по дорозі прийшлося зустрітися, яка розмова між ними відбувалася або після прослуханого тексту про Придністров'я учням пропонуємо уявити, що до їхньої школи приїхали гості 3 іншої держави, які хочуть дізнатися про Придністров’я. Одні учні по черзі розповідають, інші слухають їх і ставлять запитання. 3 метою розвитку комунікативних умінь можна здійснювати привітання мам зі святом 8 Березня, батьків з Днем захисника Вітчизни, запрошувати батьків на святкові ранки.

Роботу над формуванням мовленнєвих умінь впродовж навчального року, започатковану на уроках української мови, слід продовжувати й на уроках 3 інших навчальних предметів: уроки математики, навколишнього світу, трудового навчання сприяють збагаченню словника словами - назвами предметів, 
дій, ознак, місця, часу, простору; уроки музики - вдосконаленню орфоепічних умінь. Крім того, на уроках навколишнього світу та музики вчителі мають неабияку можливість для формування комунікативних умінь. При вивченні однакових (схожих) тем українська мова завжди має ставати предметом центральним, наприклад, під час вивчення теми ,,Звуки [3], [3'], позначення їх буквами 3 з” опрацьовуємо текст Весела зима. На уроці мови учні вчаться переказувати текст про зиму, складати діалоги за ситуативними малюнками. Планування складаємо так, що тему „Зима” пізніше вивчають й на уроках з інших предметів. На уроці образотворчого мистецтва, наприклад, учні можуть намалювати тематичний малюнок про зиму і розповісти про те, що вони намалювали. На уроці трудового навчання - виготовити ялинкові іграшки та прикраси, на уроці музики - виконувати новорічні пісні. Такими об'єднуючими темами є теми „Осінь”, „Весна”, „Місто”, „Тварини” та ін.

Отже, вивчення однакових (схожих) тем на різних уроках дає змогу засвоїти слова та сформувати пов'язані з ними аудіативні, орфоепічні та граматичні уміння, навчитися будувати діалогічні та монологічні висловлювання. I все це сприятиме ефективному оволодінню українським комунікативним мовленням.

Продуктивно-творчий етап, що має на меті формування продуктивного комунікативного мовлення, треба організувати так, щоб учні користувалися здобутими в мовленнєвій практиці знаннями, навичками, уміннями. На даному етапі слід продовжувати роботу із удосконалення частковомовленнєвих, загальномовленнєвих і комунікативних умінь. Основним на цьому етапі $\epsilon$ комунікативний метод. Цей метод використовуємо з метою формування діалогічного та монологічного мовлення в безпосередньому зв'язку з іншими методами шляхом застосування комунікативно-творчих вправ. Особливість прийомів комунікативного методу полягає в тому, що вони передбачають закріплення знань, формування й реалізацію мовленнєвих навичок та вмінь у конкретній ситуації. Екскурсії, проведення уроків на природі, розгляд картин, спеціально організовані спостереження, інші способи накопичення інформації, вражень, тобто будь-які види діяльності, що викликають потребу висловитися, розглядаємо як передумови для реалізації комунікативного методу навчання мови.

Роботу над удосконаленням умінь діалогічного мовлення слід проводити шляхом складання діалогу через створення мовленнєвих ситуацій з опорою на допоміжний матеріал. Учні практикуватимуться в побудові запитань і відповідей на них за прослуханим чи прочитаним текстом, переглянутим діафільмом, навчальною ситуацією в класі та ін. У цей період великого значення надаємо формуванню усного монологічного мовлення шляхом: 1) переказування прочитаних чи прослуханих текстів; 2) побудови власних висловлювань за серією сюжетних малюнків, побаченого або пережитого. Вправи для формування учнями саме таких умінь (будувати зв'язне висловлювання) є найскладнішими за своїм змістом та способом виконання, адже всі вміння, здобуті під час роботи зі словом, словосполученням та реченням, виступають тут в органічній єдності. Можна використовувати не лише тексти з букваря, а й з окремо виданих художніх книжок. За ними можна проводити вступні й підсумкові бесіди, переказування стисле й близьке до тексту, продовження тексту за уявою або за інформацією, одержаною на дану тему $з$ дитячих книжок, радіо- і телепередач, кінофільмів тощо.

Після сформованих умінь будувати розповіді за аналогією формуємо уміння складати розповідь за серією сюжетних малюнків (наприклад, „Прийшла 
зима”, „Прилетіли птахи” та ін.) і планом (відповідями на запитання), наприклад, учитель пропонує розглянути серію малюнків на тему „День народження”. Далі діти відповідають на питання: „,У кого сьогодні день народжсення?”, „Що приготувала мама?”, „Хто накрив святковий стіл?” „Хто прийшов привітати дівчинку”, „Які подарунки принесли діти?”, „Як пройшло свято?”. Після цього складаємо розповідь. Сюжетні малюнки та їх серії є опорою у процесі розвитку вмінь монологічного мовлення.

Навчання складати розповіді здійснюємо й на основі власних спостережень (наприклад, „Як я провів вихідний день”, „Як я провів зимові (весняні) канікули" та ін.); на основі побаченого (побудова текстів про враження після екскурсії в природу, музей); складання описової розповіді за опорними словами чи у вигляді загадок-описів. Складання розповідей на основі власних спостережень навчає дітей послідовно, творчо розповідати; удосконалювати композиційну цілісність розповіді; розвивати творчу варіативність розповіді, оціночне судження про зміст і якість придуманих розповідей, зокрема як своїх, так і ровесників; використовувати виразні засоби мовлення.

Розвитку монологічного мовлення сприяють також дидактичні ігри: „,Опuши картинку”, „Розкажи про іграшку (тварину, предмет)”, „Допоможи Незнайкові скласти розповідь” і т. ін.

Важливою умовою формування умінь комунікативного мовлення $є$ забезпечення потреби у спілкуванні українською мовою. 3 цією метою організовуємо позакласні та позашкільні заходи: свята української мови, підготовка українських народних свят (щедрування, колядування, зустрічі весни тощо), інсценізація українських казок, зустрічі однолітків зі шкіл з українською мовою навчання та ін.

Отже, навчання української мови російськомовних першокласників слід спрямовувати на формування частковомовленнєвих та загальномовленнєвих умінь, що сприятиме розвитку комунікативного мовлення. Ефективне поєднання методів, прийомів і відповідної системи вправ створюватиме умови для взаємопов'язаної роботи в усіх напрямах розвитку мовлення не лише на кожному уроці української мови, а й на уроках з інших предметів. Важливо, щоб робота над формуванням усного українського мовлення здійснювалася комплексно й поетапно (від формування частковомовленнєвих та загальномовленнєвих до комунікативних умінь), а також систематично. 